\title{
Upper Crustal Structure from the Santa Monica Mountains to the Sierra Nevada, Southern California: Tomographic Results from the Los Angeles Regional Seismic Experiment, Phase II (LARSE II)
}

\author{
by W. J. Lutter,* G. S. Fuis, T. Ryberg, D. A. Okaya, R. W. Clayton, P. M. Davis, C. Prodehl, \\ J. M. Murphy, V. E. Langenheim, M. L. Benthien, N. J. Godfrey, N. I. Christensen, \\ K. Thygesen, C. H. Thurber, G. Simila, and G. R. Keller
}

\begin{abstract}
In 1999, the U.S. Geological Survey and the Southern California Earthquake Center (SCEC) collected refraction and low-fold reflection data along a 150$\mathrm{km}$-long corridor extending from the Santa Monica Mountains northward to the Sierra Nevada. This profile was part of the second phase of the Los Angeles Region Seismic Experiment (LARSE II). Chief imaging targets included sedimentary basins beneath the San Fernando and Santa Clarita Valleys and the deep structure of major faults along the transect, including causative faults for the 1971 M 6.7 San Fernando and 1994 M 6.7 Northridge earthquakes, the San Gabriel Fault, and the San Andreas Fault. Tomographic modeling of first arrivals using the methods of Hole (1992) and Lutter et al. (1999) produces velocity models that are similar to each other and are well resolved to depths of 5-7.5 km. These models, together with oil-test well data and independent forward modeling of LARSE II refraction data, suggest that regions of relatively low velocity and high velocity gradient in the San Fernando Valley and the northern Santa Clarita Valley (north of the San Gabriel Fault) correspond to Cenozoic sedimentary basin fill and reach maximum depths along the profile of $\sim 4.3$ $\mathrm{km}$ and $>3 \mathrm{~km}$, respectively. The Antelope Valley, within the western Mojave Desert, is also underlain by low-velocity, high-gradient sedimentary fill to an interpreted maximum depth of $\sim 2.4 \mathrm{~km}$. Below depths of $\sim 2 \mathrm{~km}$, velocities of basement rocks in the Santa Monica Mountains and the central Transverse Ranges vary between 5.5 and $6.0 \mathrm{~km} / \mathrm{sec}$, but in the Mojave Desert, basement rocks vary in velocity between 5.25 and $6.25 \mathrm{~km} / \mathrm{sec}$. The San Andreas Fault separates differing velocity structures of the central Transverse Ranges and Mojave Desert. A weak low-velocity zone is centered approximately on the north-dipping aftershock zone of the 1971 San Fernando earthquake and possibly along the deep projection of the San Gabriel Fault. Modeling of gravity data, using densities inferred from the velocity model, indicates that different velocity-density relationships hold for both sedimentary and basement rocks as one crosses the San Andreas Fault. The LARSE II velocity model can now be used to improve the SCEC Community Velocity Model, which is used to calculate seismic amplitudes for large scenario earthquakes.
\end{abstract}

\section{Introduction}

Southern California is a region of significant earthquake hazard, where determination of sedimentary basin structure and location of subsurface faults can provide important information for hazard assessment. Two damaging earthquakes in the area of the San Fernando Valley, the $1971 M_{\mathrm{W}}$

*Present address: 1530 Medical Sciences Center, 1300 University Avenue, Madison, WI 53706-1532.
6.7 San Fernando and the $1994 M_{\mathrm{W}} 6.7$ Northridge earthquakes, have motivated efforts to image the deep structure of the San Fernando Valley. To address these issues, the Southern California Earthquake Center (SCEC) and the U.S. Geological Survey (USGS) conducted phase II of the Los Angeles Region Seismic Experiment (LARSE II), part of which consisted of a transect, line 2, crossing from south to north the Santa Monica Mountains, San Fernando Valley, 
Santa Susana Mountains, Santa Clarita Valley, central Transverse Ranges, Mojave Desert, Tehachapi Mountains, and Sierra Nevada (Fig. 1).

A similar experiment (LARSE I) was conducted in 1994 along a corridor through the east-central Los Angeles region, traversing the Los Angeles basin, San Gabriel Valley, San Gabriel Mountains, and Mojave Desert. Inverse and forward modeling of first arrivals (Lutter et al., 1999; Fuis et al., 2001b) provided an image of velocity structure that, when combined with oil-test well data (Brocher et al., 1998) and laboratory rock-velocity measurements (McCaffree Pellerin and Christensen, 1998), constrained interpretation of basin depth (Los Angeles and San Gabriel Valley basins), the geometry of the Sierra Madre Fault at depth, and the subsurface lateral extent of the Pelona Schist. Ryberg and Fuis (1998) and Fuis et al. (2001b) have identified a gently north-dipping bright reflective layer in the middle crust of the San Gabriel Mountains that they interpret as a fracture zone containing fluids. This reflective zone is interpreted to be part of a decollement connecting the San Andreas Fault (SAF) with re-

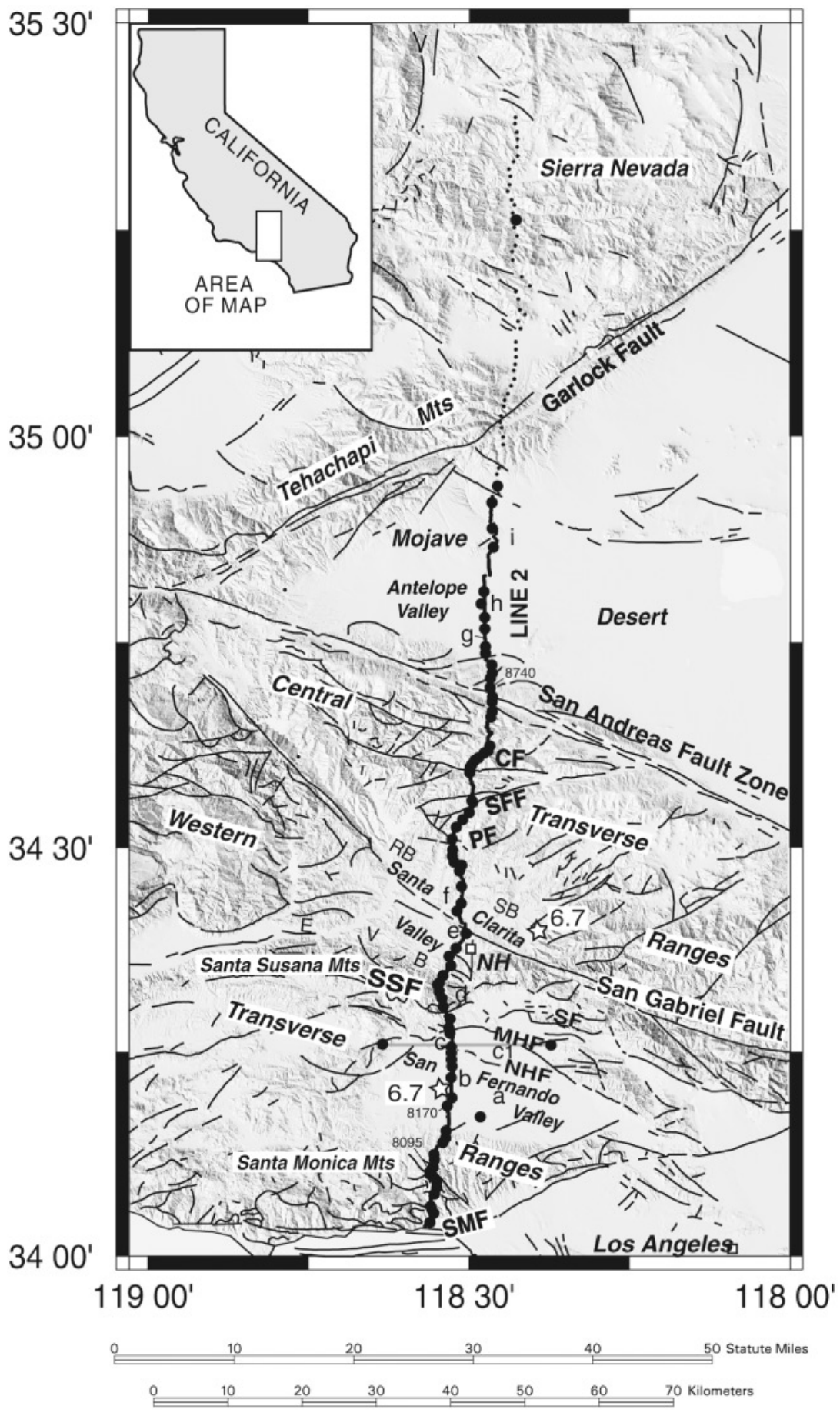

Figure 1. Fault map of part of southern California showing explosions (large dots) and receivers (small dots) along the main line (line 2) of the 1999 LARSE II. Explosions for which shot gathers are shown in Figure 2 are labeled (8095, 8170, and 8740). Line 2 is $150 \mathrm{~km}$ long with shotpoint spacing $\sim 1 \mathrm{~km}$ in the southern $80 \mathrm{~km}$ of the line and corresponding receiver spacing of $100 \mathrm{~m}$. The northern part of the line was more sparsely shot and recorded. An eastwest cross line in the northern San Fernando Valley modeled by Thygesen (2003) is shown as a gray line. Stars indicate the epicenters of the $1971 M_{\mathrm{W}} 6.7$ San Fernando and $1994 M_{\mathrm{W}}$ 6.7 Northridge earthquakes. White squares indicate the position of Newhall (NH) and Los Angeles, California. EVB, east Ventura basin; RB, Ridge basin; SB, Soledad basin; CF, Clearwater Fault; MHF, Mission Hills Fault; NHF, Northridge Hills Fault; PF, Pelona Fault; SMF, Santa Monica Fault; SF, San Fernando Fault; SFF, San Francisquito Fault; and SSF, Santa Susana Fault. Locations for oil wells are abbreviated (a) Leadwell 1, Standard Oil of California (Brocher et al., 1998); (b) Frieda J. Clark 1, Standard Oil of California (Brocher et al., 1998); (c) Greenmann Community well, Sunray Oil (Shields, 1977); (c1) Burnet 1 and 2 wells, Standard Oil of California (Brocher et al., 1998); (d) Mobil Macson Mission, Mobil Oil Corp. (Tsutsumi and Yeats, 1999); (e) Circle J 2, Mobil Oil Corp. (Stitt, 1986); (f) R. W. Young Walker 1 (Stitt, 1986); (g) H \& K Exploration Co. (Dibblee, 1967); (h) Goldberg 110, Hunt Oil USA (API 037-24010, California Division Oil and Gas); and (i) Meridian Oil Co. (Dibblee, 1967). 
verse faults to the south, including the Sierra Madre Fault and the causative fault for the 1987 M 5.9 Whittier Narrows earthquake.

In this study, we have produced $2 \mathrm{D}$ velocity models for line 2 of the LARSE II experiment based on inversion of first arrivals using damped least-squares (DLS) and smoothingconstraint inversion (SCI) methods as described by Lutter et al. (1999). These models are resolved to depths of 5-7.5 km. In addition, we have used the tomographic algorithm of Hole (1992) to produce a 3D velocity model. Of these models, we present a final 2D DLS model and compare it with a 3D model slice along the LARSE II transect.

We compare our final velocity models with a large number of other geological and geophysical data sets and models. These include surface geology, sonic logs from oil-test wells (Brocher et al., 1998), laboratory measurements of basement rock velocity (McCaffree Pellerin and Christensen, 1998), gravity (Wooley and Langenheim, 2001), relocated aftershocks of the San Fernando and Northridge earthquakes (Hauksson, 2000), and velocity models derived from independent forward modeling of LARSE II refraction data (Thygesen, 2003), inversion of earthquake arrival times (Hauksson, 2000), and compilation of oil-test well data (Magistrale et al., 2000).

\section{Geological Setting}

The LARSE II transect (Fig. 1) crosses the complex geology of the western and central Transverse Ranges, Mojave Desert, Tehachapi Mountains, and Sierra Nevada. The western Transverse Ranges, including the Santa Monica Mountains, San Fernando Valley, and Santa Susana Mountains, are believed to have rotated more than $90^{\circ}$ clockwise since the early Miocene from a position offshore of the Peninsular Ranges (Hornafius et al., 1986; Crouch and Suppe, 1993). The southernmost range in this province, the Santa Monica Mountains, is an anticlinorium containing in its core Mesozoic igneous and metamorphic rocks (Dibblee, 1992). These rocks, which include the Santa Monica Slate, are similar to rocks of the Peninsular Ranges (e.g., Crouch and Suppe, 1993). The core rocks of the anticlinorium are overlain by Cenozoic clastic sedimentary and volcanic rocks that are offset by gently dipping detachment faults. The entire anticlinorium is faulted on its southern flank by the leftlateral/reverse Malibu Coast-Santa Monica-Hollywood Fault system (Fig. 1).

The San Fernando Valley is underlain by a gently northdipping Miocene to Holocene clastic sedimentary section (Dibblee, 1992) that, in the south, overlies an igneous basement at depths of 1.3-1.4 km. However, in the north and northeast, the sedimentary section overlies an unknown basement at depths exceeding $3 \mathrm{~km}$ (Tsutsumi and Yeats, 1999; Langenheim et al., 2000, 2001). Historic faulting in and beneath the San Fernando Valley has occurred along conjugate reverse faults: (1) the north-dipping San Fernando Fault, which ruptured from a depth of $13-15 \mathrm{~km}$ beneath the eastern Santa Clarita Valley to the surface in the northeastern San Fernando Valley in the 1971 M 6.7 San Fernando earthquake (Allen et al., 1971, 1975; USGS Staff, 1971; Heaton, 1982) and (2) the south-dipping Northridge Fault, which ruptured from a depth of $16 \mathrm{~km}$ in the southern San Fernando Valley to a depth of $8 \mathrm{~km}$ in the northern part of the valley (Hauksson et al., 1995; Mori et al., 1995). Mori et al. (1995) suggested the northeastern part of the Northridge aftershock zone is truncated by the southwestern part of the San Fernando aftershock zone. Tsutsumi and Yeats (1999) suggested that the San Fernando Fault branches at depth and extends southward of the 1971 surface breaks (SF, Fig. 1) to the Northridge Hills Fault (NHF), and they interpret the 1971 surface breaks and the Mission Hills Fault (MHF) as upward splays from this southward extension. Fuis et al. (2003a) linked the San Fernando earthquake via a northdipping reflective zone to the SAF.

"Santa Clarita Valley" is an informal name for the broad valley along the Santa Clara River in the area of Newhall, California (Fig. 1). This valley straddles two different sedimentary basins, separated by the San Gabriel Fault (SGF). The east Ventura sedimentary basin (EVB), south of the SGF (Fig. 1), contains a Cenozoic section that, in its upper part, is thickened compared to a similar section in the San Fernando Valley and thrust over that section along the Santa Susana Fault (SSF) and MHF (Winterer and Durham, 1954; Yeats, 1987). Basement depth in the EVB ranges from 1.5 to $4 \mathrm{~km}$ (Stitt, 1986; Dibblee, 1996). North of the SGF are the Oligocene to Quaternary Soledad sedimentary basin, east of line 2, and the upper Miocene and Pliocene Ridge sedimentary basin, west of line 2 (Fig. 1). Maximum basement depth is $>3 \mathrm{~km}$ north of the SGF along the LARSE II transect (Stitt, 1986). The SSF, on the south side of the EVB, has the youngest age (Quaternary) and greatest displacement $(>4$ $\mathrm{km}$ along the transect) of a series of steeply north- and southdipping reverse faults in the Santa Susana Mountains (Yeats, 1987; Yeats et al., 1994). Its shallow dip at the surface increases to as much as $60^{\circ}$ at $1-2 \mathrm{~km}$ below sea level. The SGF, on the north side of the EVB, is an older branch of the SAF system, that was most active during the period $\sim 10-5$ $\mathrm{Ma}$ and has a total offset of $40-60 \mathrm{~km}$ in the region of line 2 (see summary in Powell [1993]). Currently, this fault is active as a right-lateral/reverse fault but at a low slip rate ( $\sim 1 \mathrm{~mm} / \mathrm{yr}$ ) (Yeats et al., 1994). Oil wells indicate the SGF dips steeply northward at $70^{\circ}-75^{\circ}$ to a depth of $\sim 2 \mathrm{~km}$ (Stitt, 1986).

Between the Santa Clarita Valley and the SAF are three terranes: (1) Sierra Pelona, underlain by the Mesozoic Pelona Schist; (2) Bee Canyon/San Francisquito Valley, underlain by lower Tertiary sedimentary rocks; and (3) the Liebre Mountain/Sawmill Mountain block, underlain by preЄambrian gneiss and Mesozoic granitic rocks. The Clearwater Fault (CF) separates the Liebre Mountain/Sawmill Mountain block from the Bee Canyon/San Francisquito Valley basin. The SAF in this region has experienced $160 \mathrm{~km}$ 
of right slip in the last 4 million yr (Matti et al., 1985; Meisling and Weldon, 1989).

North of the SAF along line 2, Mesozoic granitic rocks and schist are overlain in the western Mojave Desert, or Antelope Valley, by Oligocene and younger sedimentary and volcanic rocks (Dibblee, 1967). Beginning about 104 $\mathrm{km}$ north of the coast, line 2 crosses igneous and metamorphic rocks of the northwestern Mojave Desert, Tehachapi Mountains, and Sierra Nevada (Dibblee, 1967).

\section{Data}

The explosion survey along the LARSE II transect (line 2) consisted of 78 shots and 954 receivers (a stationary array), with shots spaced $\sim 1.2 \mathrm{~km}$ apart and stations $100 \mathrm{~m}$ apart along the southern half of the 150-km-long line (Fig. 1) (Fuis et al., 2001a; Murphy et al., 2002). In the Mojave Desert, shotpoint spacing averaged $2.75 \mathrm{~km}$, and there was one shot in the southern Sierra Nevada, at model coordinate $136 \mathrm{~km}$. Station spacing remained $100 \mathrm{~m}$ through most of the Mojave Desert but increased to $1000 \mathrm{~m}$ in the Tehachapi Mountains and southern Sierra Nevada. Shot size ranged from 45 to $1800 \mathrm{~kg}$. Signal-to-noise ratios were remarkably good along the transect, given the urban areas that were traversed (Fig. 2).

\section{Methods and Modeling}

Two-dimensional iterative DLS and SCI methods (Lutter et al., 1999) were applied to approximately 20,000 firstarrival travel times from 64 shots along line 2. Pickable first arrivals were recorded to at least $70 \mathrm{~km}$ for $25 \%$ of these shots and to $50 \mathrm{~km}$ for most shots. Model distances for the 2D inversions are based on the radial distance from the southernmost shot, located in the Santa Monica Mountains about $2 \mathrm{~km}$ north of the coast. The average azimuth of line 2 is $7.5^{\circ}$ east of north. Ray coverage extends to a maximum depth of $10-15 \mathrm{~km}$ for all of the $2 \mathrm{D}$ velocity models.

An initial SCI model inversion provided a starting model for coarser- and finer-grid DLS inversions that yielded the final 2D model and estimates of resolution. Both the DLS and SCI models used a bicubic-spline interpolation between velocity nodes (see Lutter et al. [1999] for details). In both the coarser-grid SCI and DLS models, a total of 372 velocity nodes were positioned at a horizontal grid interval of 7.5 $\mathrm{km}$. The vertical grid interval increased from $1 \mathrm{~km}$ to a value of $2 \mathrm{~km}$ at depths greater than $2 \mathrm{~km}$ below sea level. The SCI inversion successfully fit 7500 travel times through this model to an average root mean square (rms) travel-time error of $65 \mathrm{msec}$. The coarser-grid DLS inversion fit the travel times to $62 \mathrm{msec}$. Diagonal resolution values $>0.4$ for the DLS coarser-grid model extend to depths of $5-7.5 \mathrm{~km}$ in the Mojave Desert and southward and occur in the colored region of Figure 3B.

For the finer-grid DLS inversion model (Fig. 3B), a total of 915 model parameters were positioned at a horizontal grid interval of $2.5 \mathrm{~km}$. The vertical grid interval is $1 \mathrm{~km}$ at depths shallower than $2 \mathrm{~km}$ below sea level and increases to $2 \mathrm{~km}$ at greater depths. The finer-grid DLS model lowers the rms error to $53 \mathrm{~ms}$ and resolves image detail to a depth of 3-4 $\mathrm{km}$ within the model distance range of approximately 10 $110 \mathrm{~km}$ (see Fig. 4). Model details at greater depth do not change significantly from the coarser-grid DLS model. Consequently, we use the coarser-grid DLS model resolutions $(>0.4)$ as a better indicator of model reliability for the depth range of 4-8 km. An alternate finer-grid SCI model imaged comparable model detail and fit travel-time data to $47 \mathrm{msec}$. This model required 1818 parameters positioned at grid intervals half as wide as the coarser-grid model intervals. We use the finer-grid DLS model (Fig. 3B) as the final 2D model because of superior resolution at shallow depth (Fig. 4) over resolutions calculated for the finer-grid SCI model.

Three-dimensional velocity models were constructed using the method of Hole (1992) to evaluate the effects of crooked-line geometry and to possibly improve delineation of near-surface detail. The method of Hole (1992) allows smoothing to be applied to a well-parameterized model that maximizes the number of parameters while minimizing undersampling. Backprojection along ray paths yields the smallest model norm for the slowness perturbation but can also produce an image with significant smearing along the ray path (Hole, 1992). Smoothing is applied to adjacent model cells to interpolate between rays using a 3D moving average filter.

The 3D model grid formed a box $160 \mathrm{~km}$ long (approximately north-south) by $10 \mathrm{~km}$ wide (approximately eastwest) by $32 \mathrm{~km}$ deep. Three sets of iterated inversions were performed using constant horizontal and vertical grid intervals of $2 \mathrm{~km}, 1 \mathrm{~km}$, and $0.5 \mathrm{~km}$ per set. The final model fits more than 20,000 travel times to an rms error of $41 \mathrm{msec}$ based on using 64 shots along or near line 2 (Fig. 1). The central slice from this 3D velocity model (Fig. 3C) is aligned along line 2 . With one exception, shots and receivers for line 2 fall within a \pm 2 -km offset from the central slice.

Similarity of the finer-grid DLS model (Fig. 3B; $2.5-\mathrm{km}$ horizontal grid interval) and the 3D model slice (Fig. 3C; $0.5-\mathrm{km}$ horizontal grid interval) suggest model details are robust. Diagonal resolutions for the 3D velocity model were not available from the 3D inversion coding. Diagonal resolutions $>0.4$ from the coarser-grid DLS model (colored region, Fig. 3B) serve as a guide to 3D model reliability, and we show a similar colored region in Figure 3C. Although our choice of a resolution value of 0.4 for model reliability is somewhat arbitrary, it appears to delineate features that are robust (Lutter et al., 1999).

\section{Discussion}

\section{Comparison of Inversion Models}

In both models, upper crustal low-velocity regions (1.8$5 \mathrm{~km} / \mathrm{sec}$ ) are seen in the San Fernando, Santa Clarita, and 

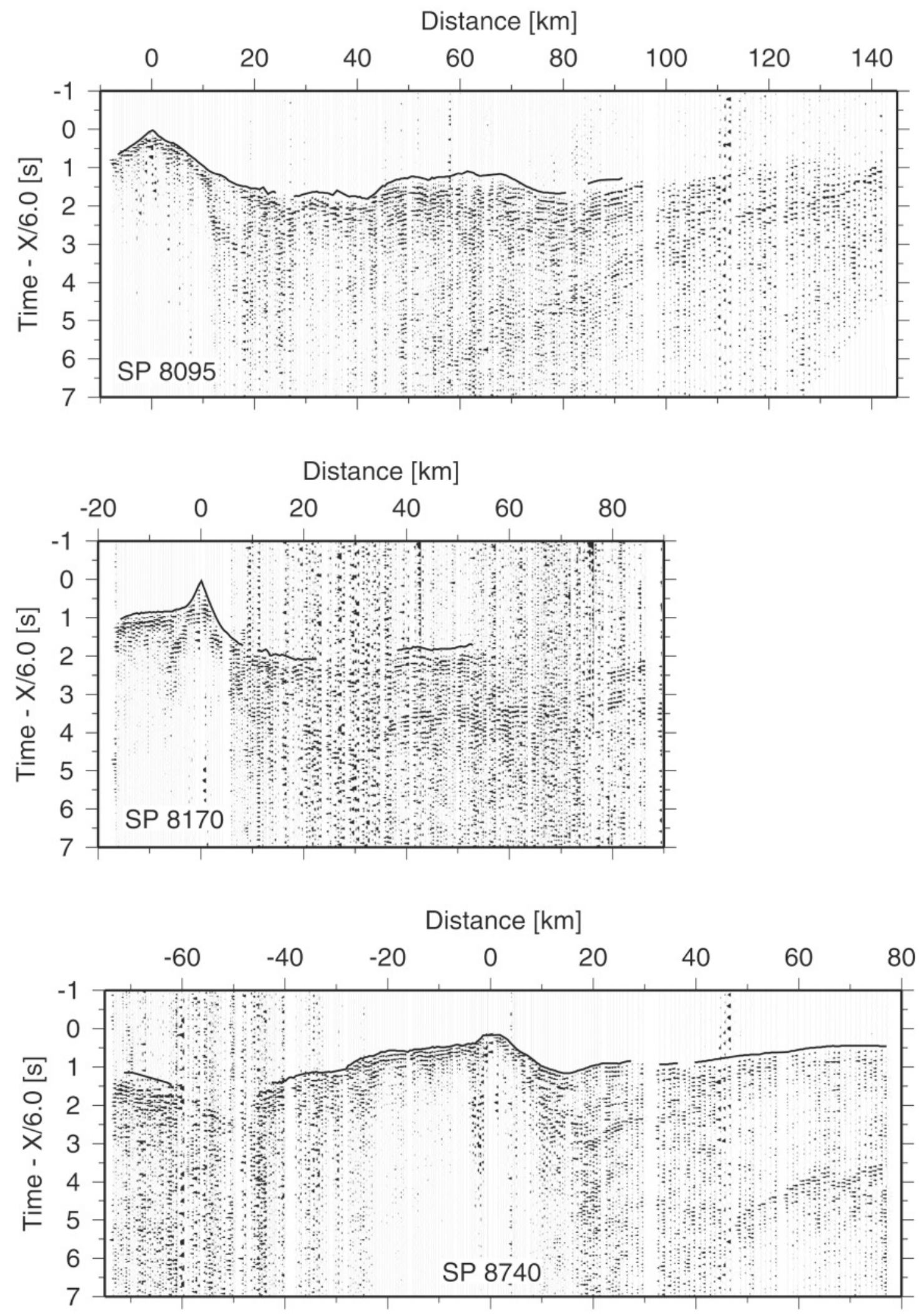

Figure 2. Shot gathers from LARSE II with predicted travel times (solid line) from the 2D DLS tomography model (Fig. 3B). Every fifth trace is shown for the majority of each shot gather. Traces are bandpass filtered from 1 to $12 \mathrm{~Hz}$. Shot gathers 8095, 8170, and 8470 were positioned within the Santa Monica Mountains, the southern San Fernando Valley, and just north of the SAF, respectively. See Figure 1 for locations of shotpoints. Traveltime delays at positive offset seen on gathers 8170 and 8470 are associated with lowervelocity sedimentary rocks beneath the San Fernando and Antelope Valleys. 


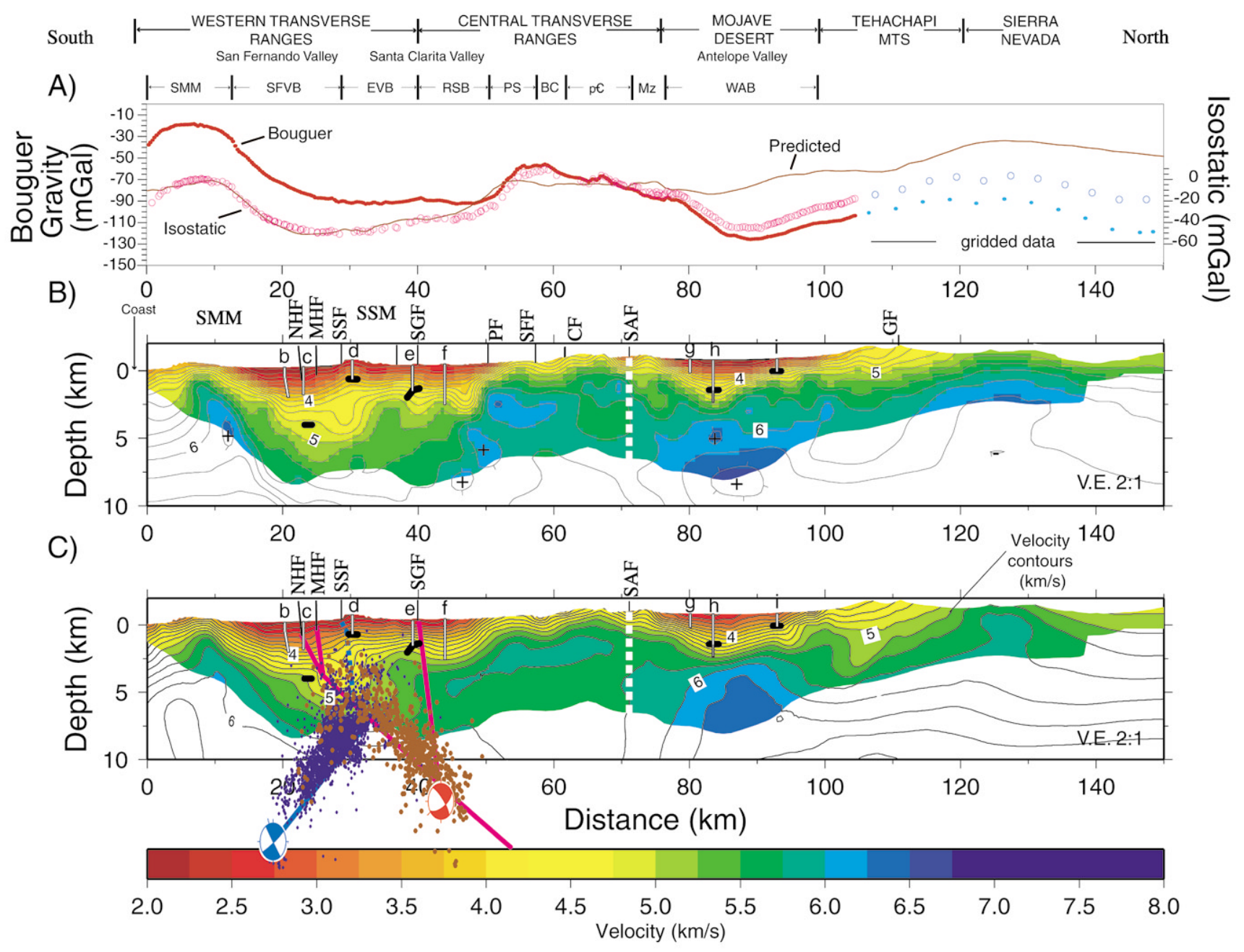

Figure 3. (A) Gravity data along the LARSE II transect. Predicted gravity curve is calculated from the 3D velocity model (see panel C) using velocity-density relationships discussed in the text. Bouguer (solid red and blue circles) and isostatic gravity (open magenta and blue circles) data show highs associated with the Santa Monica Mountains and central Transverse Ranges and lows associated with the San Fernando, Santa Clarita, and Antelope Valley basins. Basins are labeled at the top of the figure: SFVB, San Fernando Valley basin; EVB, east Ventura basin; RSB, Ridge and Soledad basins (positioned west and east of the LARSE II line 2, respectively); BC, Bee Canyon basin (subbasin of the Soledad basin); and WAB, west Antelope Valley basin. The east Ventura and Ridge/Soledad basins together underlie the Santa Clarita Valley along line 2. Surface bedrock geologic units are PS, Pelona Schist; p€, pre- $€$ ambrian gneiss; Mz, Mesozoic intrusives. (B) DLS inversion model (finer gridded version; see text), from the method of Lutter et al. (1999), fits 7500 travel times to an average rms error of $53 \mathrm{msec}$. Faults are abbreviated as in Figure 1. Additional faults are abbreviated as follows: GF, Garlock Fault; SAF, San Andreas Fault (dashed white line); and SGF, San Gabriel Fault. The Santa Monica Mountains and Santa Susana Mountains are abbreviated SMM and SSM, respectively. Thin black lines are velocity contours (contour interval, $0.25 \mathrm{~km} / \mathrm{sec}$ ). Heavy black line segments are sediment-basement contacts determined from oil-test well data within 0-2.5 km of line 2, or, in the San Fernando Valley, from a refraction cross line. See Figure 1 for well identifications; gray fill in lower part of well h represents sedimentary basement rocks, where the sonic log indicates a velocity of $\sim 5 \mathrm{~km} / \mathrm{sec}$. (C) $3 \mathrm{D}$ velocity model, from the method of Hole (1992), fits 20,000 travel times to an rms error of $41 \mathrm{msec}$. Shown is central slice of 3D model, which lies along line 2 and is coincident with DLS model profile of (B). Faults, sediment-basement contacts, and oil-test wells are the same as in (B). A diagonal resolution value of 0.4 from the coarsergrid DLS model (see text) truncates the colored regions of both models. The Northridge (blue) and San Fernando (red) mainshock focal mechanisms (vertically exaggerated) are superimposed. Aftershocks of Northridge (blue) and San Fernando (red-brown) earthquakes are from Fuis et al. (2003a). (These were relocated using the model of Hauksson [2000] improved using LARSE II shots; they are projected onto line 2 from a zone $0-10 \mathrm{~km}$ east of line 2.) Heavy blue line, causative fault for Northridge earthquake; heavy magenta lines, faults of the San Fernando Fault system (from Fuis et al., 2003a). 


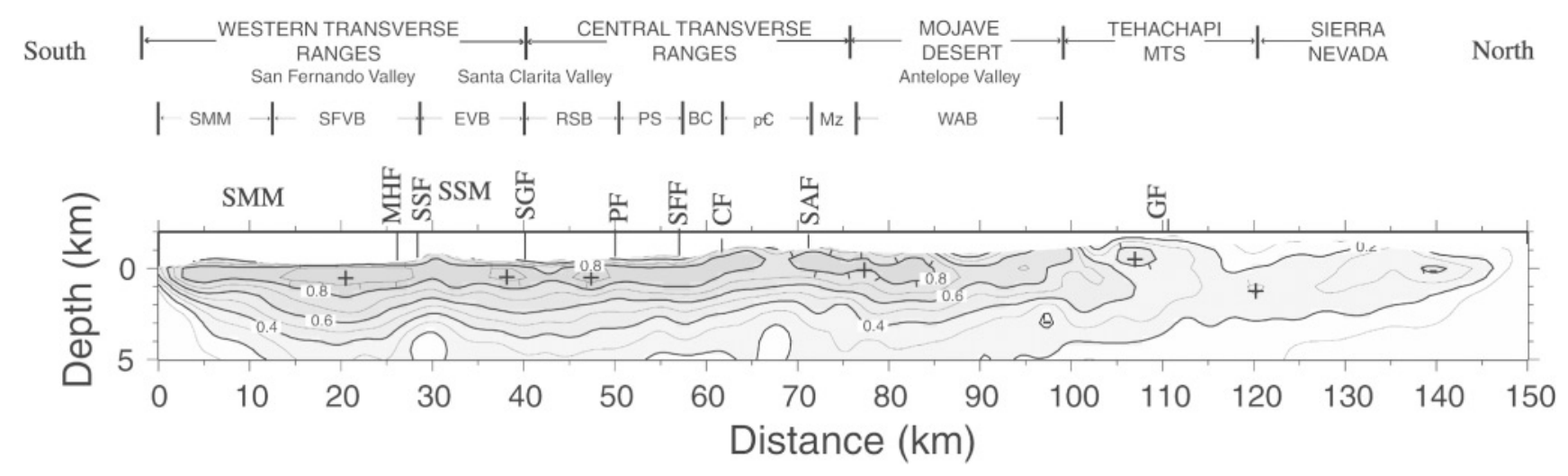

Figure 4. Diagonal resolutions contoured at an interval of 0.1 for the finer-grid DLS inversion model (Fig. 3B). See Figure 3 for identification of labels at top of figure.

Antelope Valleys, and high-velocity regions $(>5 \mathrm{~km} / \mathrm{sec})$ are seen in the Santa Monica Mountains, central Transverse Ranges, and the Tehachapi Mountains (Fig. 3). A velocity contrast between the central Transverse Ranges and the Mojave Desert at depths $>2 \mathrm{~km}$ can be observed at model coordinate $70 \mathrm{~km}$, near the surface trace of the SAF. Further comparisons between the two models are apparent in the following discussion, where we compare them to other data sets.

Basement Depth in Sedimentary Basins: Comparison of Inversion Models to Independent Forward Modeling and Oil-Test Well Data

Sedimentary basin fill underlying the San Fernando, Santa Clarita, and Antelope Valleys has low velocities (1.8$5 \mathrm{~km} / \mathrm{sec})$ and high velocity gradients $(0.5 \mathrm{~km} / \mathrm{km} \mathrm{sec}$ to 1.25 $\mathrm{km} / \mathrm{km} \mathrm{sec}$ ) (Fig. 3). In the San Fernando Valley, velocities and velocity gradients are similar to those seen in sonic well$\log$ data (discussed later). The depth of sedimentary rocks is, however, not well established in our inversions.

Thygesen (2003) modeled refraction data along a 20$\mathrm{km}$-long, east-west cross line centered on line 2 in the northern San Fernando Valley (Fig. 1), using the method of Zelt and Smith (1992). She determined depth to a $4.9 \mathrm{~km} / \mathrm{sec}$ basement layer at $4.3-\mathrm{km}$ depth in the region beneath line 2 . This depth has been confirmed by preliminary forward modeling of refraction data along line 2 by Fuis et al. (2003b), using the method of Luetgert (1992). This contact lies between the 4.75- and $5.0-\mathrm{km} / \mathrm{sec}$ contours. The deepest well penetrations within $2 \mathrm{~km}$ of line 2 in the San Fernando Valley encounter middle Miocene and Cretaceous sedimentary rocks (wells b and c, respectively, Fig. 3) (Shields, 1977; Brocher et al., 1998; Thygesen, 2003). Below the modeled basement contact we interpret Mesozoic metamorphic and igneous rocks (Santa Monica Slate and Mesozoic granitic rocks), which also form the basement core of the Santa Monica Mountains, to be present.

In the Santa Clarita Valley, well data near LARSE line 2 indicate that clastic sedimentary rocks extend to at least 3- km depth (Stitt, 1986) (see well f, Fig. 3), corresponding to our $5.0-\mathrm{km} / \mathrm{sec}$ contour. Basement must lie still deeper.

Wells in the central and northern Antelope Valley penetrate basement (wells $h$ and i, Fig. 3). Well i, in the northern part of the valley, bottoms in granitic rocks at $1-\mathrm{km}$ depth. Well $\mathrm{h}$, in the central part of the valley, bottoms in clastic sedimentary rocks at $3.2 \mathrm{~km}$, passing through an $\sim 100-\mathrm{m}$ interval at $2.4 \mathrm{~km}$, where a sonic $\log$ indicates a rise in velocity from $\sim 4.0$ to $\sim 5.0 \mathrm{~km} / \mathrm{sec}$. If we consider as "basement" rocks with velocities greater than or equal to $5 \mathrm{~km} /$ $\mathrm{sec}$, then basement is a mixed unit in the Antelope Valley, containing both granitic and sedimentary rocks. Its maximum depth is $2.4 \mathrm{~km}$ in the central Antelope Valley, where it lies at about our $4.5 \mathrm{~km} / \mathrm{sec}$ in both models (Fig. 3B,C).

In summary, in the deepest parts of the San Fernando and Antelope Valleys where independent modeling of refraction data or well data has confirmed the presence of basement rocks (i.e., rocks with velocities of $\sim 5 \mathrm{~km} / \mathrm{sec}$ or greater), our inversion models give velocities that are slightly lower, $4.5-5.0 \mathrm{~km} / \mathrm{sec}$. This small difference may arise from the gridded parameterization of our inversions, where averaging and smoothing takes place.

Note that two wells in the EVB, between the SGF and SSF (wells d and e, Fig. 3), penetrate crystalline rock beneath the sediments at depths where our inversions indicate velocities of 3.75-4.5 km/sec. Well d is projected onto line 2 from $\sim 2.5 \mathrm{~km}$ east in an area of structural complexity ("San Fernando lateral ramp" of the SSF; Tsutsumi and Yeats, 1999). Well e penetrates a bedrock ridge that flanks the SGF on its southwest side (Yeats et al., 1994).

\section{Comparison of Inversion Models to Well Logs}

The sonic log for the oil-test well, Frieda J. Clark 1, at model distance $20 \mathrm{~km}$ (Fig. 5A), agrees well on average with our models from the surface to nearly $1 \mathrm{~km}$ below the surface. Between 1- and 2-km depth below the surface, however, it is slower by an average of $\sim 0.5 \mathrm{~km} / \mathrm{sec}$. The sonic $\log$ for the Burnet 1 and 2 wells, at model distance $23 \mathrm{~km}$ (Fig. 5B), agrees well on average with our models from the 

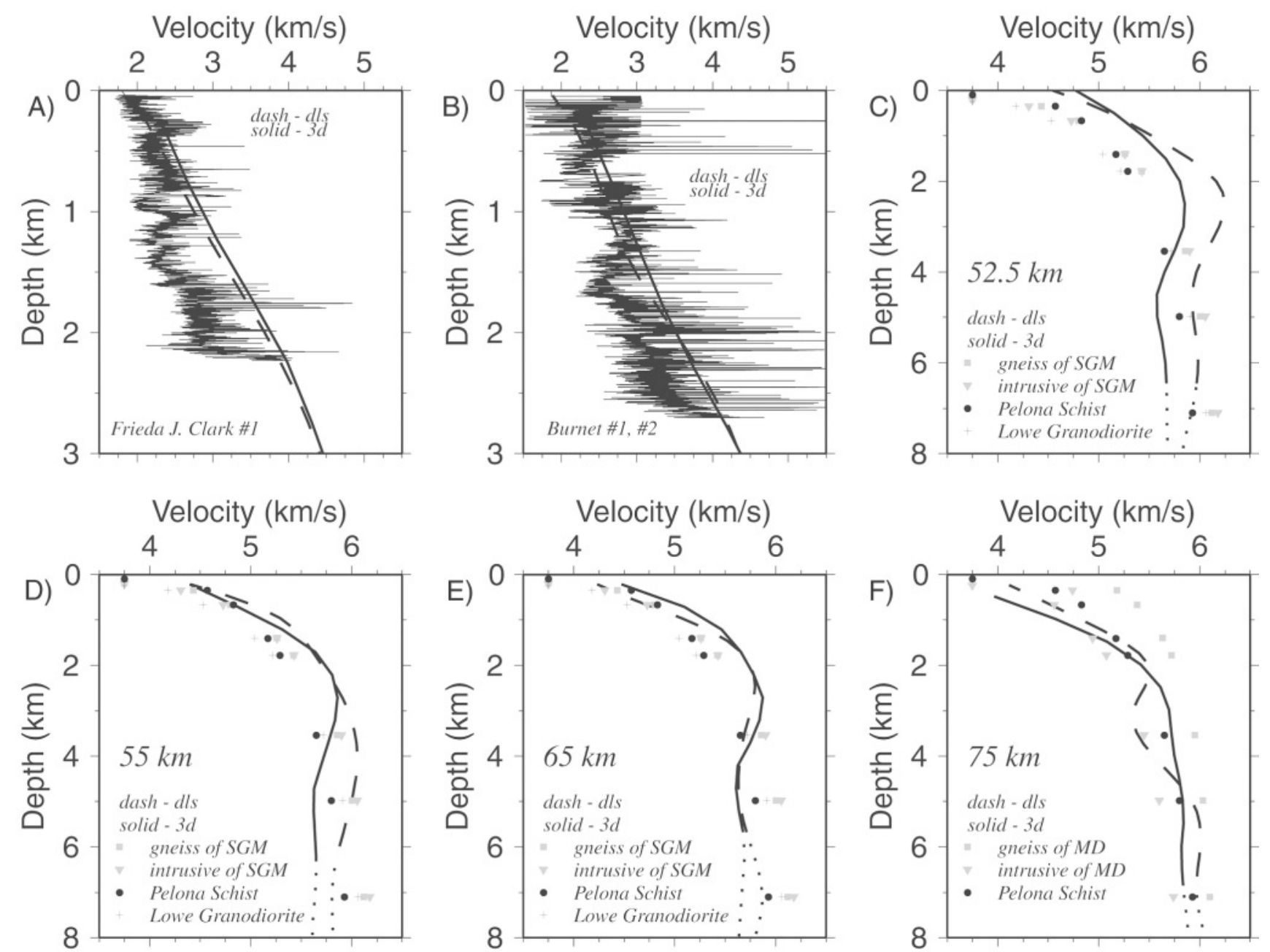

Figure 5. (A) Sonic velocity log (interval velocity) for the Frieda J. Clark 1 well in the San Fernando Valley (from Brocher et al., 1998). This well is $1.3 \mathrm{~km}$ east of line 2 at model coordinate $20 \mathrm{~km}$ (see Figs. 1 and 3 for location). Superposed are model velocity-depth curves from both models in Figure 3 (dashed line, 2D velocity model; solid line, 3D velocity model). The Frieda J. Clark 1 bottoms in middle Miocene conglomerate. (B) Composite sonic velocity $\log$ for the Burnet wells $6.25 \mathrm{~km}$ east of line 2 at model coordinate $23 \mathrm{~km}$ (see Fig. 1 for location). Velocity-depth curves are superimposed. (C) Velocity-depth curves from Figure 3B,C at model coordinate $52.5 \mathrm{~km}$ (between the Pelona and San Francisquito Faults beneath outcrops of Pelona Schist). These curves are compared with average velocity-depth curves for samples of rocks along LARSE line 1 that were examined in the laboratory by McCaffree Pellerin and Christensen (1998). SGM, San Gabriel Mountains; MD, Mojave Desert. (D) Velocity-depth curves and average sample curves for model coordinate $55 \mathrm{~km}$ (between the Pelona and San Francisquito Faults). (E) Velocity-depth curves and average sample curves for model coordinate $65 \mathrm{~km}$ (positioned between the CF and SAF). (F) Velocity-depth curves and average sample curves for model coordinate $75 \mathrm{~km}$ (north of the SAF). Velocitydepth curves are dotted in regions of low resolution (uncolored regions of Fig. 3B,C).

surface to $\sim 1.5 \mathrm{~km}$ below the surface. From that depth, to $2.6 \mathrm{~km}$ below the surface, this sonic log is also slower by an average of $0.2-0.4 \mathrm{~km} / \mathrm{sec}$. The Frieda J. Clark and Burnet wells are 1.3 and $6.25 \mathrm{~km}$ east of the LARSE II line, respectively. The discrepancies between our inversion velocity models and the sonic logs might result from the possibility that refracted energy from the LARSE II explosions does not fully sample low-velocity zones in the Cenozoic sedimentary rocks.
Igneous and metamorphic rocks have been penetrated by oil wells in a few locations in the San Fernando, Santa Clarita, and Antelope Valleys. One well, Leadwell 1 (well a, Fig. 1), located $6 \mathrm{~km}$ east of line 2 in the southeastern San Fernando Valley, penetrated quartz diorite at $1.48 \mathrm{~km}$ from the surface (see Brocher et al., 1998; Tsutsumi and Yeats, 1999). The sonic velocity of the quartz diorite increases from 4.5 to $5.0 \mathrm{~km} / \mathrm{sec}$ in the $70-\mathrm{m}$ interval of the quartz diorite that was drilled, indicating that this basement rock type has 
a velocity greater than $5 \mathrm{~km} / \mathrm{sec}$ beneath the Cenozoic cover, which is consistent with the earlier discussion.

\section{Our Inversion Models in Areas of Igneous and} Metamorphic Outcrop

Through the outcrop areas of igneous and metamorphic rocks along line 2, our models indicate near-surface zones of steep velocity gradient extending as deeply as $2 \mathrm{~km}$. These zones are interpreted as regions of open cracks and weathering (e.g., Stierman and Kovach, 1979; Mooney and Schapper, 1995; McCaffree Pellerin and Christensen, 1998).

Model velocities range from 5.5 to $6.25 \mathrm{~km} / \mathrm{sec}$ beneath these surficial, high-gradient zones. In the Santa Monica Mountains, basement rocks beneath this $\sim 2$-km-deep zone have velocities of $5.75-6.0 \mathrm{~km} / \mathrm{sec}$, where well resolved. These velocities correspond to Mesozoic granitic rocks and the Santa Monica Slate that crop out just east of line 2. In the central Transverse Ranges, basement rocks beneath this zone have velocities that average $5.75-6.0 \mathrm{~km} / \mathrm{sec}$ in the southern part of the ranges and $5.5-5.75 \mathrm{~km} / \mathrm{sec}$ in the northern part. The southern part of the ranges is underlain by Pelona Schist (between the Pelona and San Francisquito Faults, Fig. 3) and lower Tertiary sedimentary rocks (between the San Francisquito Fault and CF). In contrast, the northern part of the ranges is underlain by pre- $€$ ambrian igneous and metamorphic rocks and Mesozoic igneous rocks (between the CF and SAF) (Jennings, 1977). Immediately north of the SAF, velocities beneath the surficial zone range from 5.25 to $6.25 \mathrm{~km} / \mathrm{sec}$; Mesozoic granitic rocks and schist are exposed in this area.

\section{Faults in Our Inversion Models}

Tabular low-velocity zones and/or lateral velocity contrasts that correlate with the surface traces of faults allow one to interpret faults in velocity models (Lutter et al., 1999). The best evidence of faulting is seen in our models at the SAF. A 5-km-wide low-velocity zone, centered, or nearly centered, on the surface trace of the SAF is imaged in the upper $2 \mathrm{~km}$ of the DLS model (Fig. 3B). This low-velocity zone, less obvious in the central slice of the 3D model (Fig. 3C), is more conspicuous in a 3D slice positioned 1 $\mathrm{km}$ east of line 2 . A low-velocity zone along the deep projection of the SGF (model coordinate $40 \mathrm{~km}$, depths of 2.5$5 \mathrm{~km}$ see Fuis et al., 2003a) can be observed in the DLS model (Fig. 3B). The lack of a low-velocity zone in the 3D image (Fig. 3C) may be related to $2 \mathrm{D}$ versus 3D geometry or may be due to smoothing characteristics of the Hole (1992) method.

A velocity contrast between the central Transverse Ranges and the Mojave Desert at depths $>2 \mathrm{~km}$ can be observed near model coordinate $70 \mathrm{~km}$. Immediately north of the SAF, basement velocity beneath this surficial zone is $5.25-5.5 \mathrm{~km} / \mathrm{sec}$, slightly lower than immediately south of the SAF $(5.5-5.75 \mathrm{~km} / \mathrm{sec})$. Although poorly resolved at greater depths $(4-6 \mathrm{~km})$, the basement velocity is higher north of the SAF $(5.75-6.25 \mathrm{~km} / \mathrm{sec})$ than south of the SAF $(5.75-6.0 \mathrm{~km} / \mathrm{sec})$. Thus, the SAF appears to separate different velocity structures.

A deep structural contrast similar to that at the SAF is also observed at the $\mathrm{CF}$ (model distance $61 \mathrm{~km}$, Fig. 3), at least in the DLS model (Fig. 3B) with higher velocities at depths $>2 \mathrm{~km}$ south of the CF and lower velocities north of the CF. Surficial outcrops would imply the opposite contrast, as lower Tertiary sedimentary rocks are exposed south of the fault and pre- $€$ ambrian gneiss and schist and Mesozoic intrusive rocks are exposed north of the fault (see Jennings, 1977). The dip of this fault is poorly resolved both from image detail and from geology, but the straight trace of the $\mathrm{CF}$ across rugged terrane suggests that this fault is nearly vertical in dip (Crowell, 2003). Modeling of aeromagnetic data indicates a steep north dip for the CF (Wooley et al., 2001). The Pelona Fault, known to be a high-angle fault dipping southward toward the Soledad basin depocenter (Hendrix and Ingersoll, 1987), may be partially responsible for the strong velocity contrast at $\sim 50 \mathrm{~km}$.

Our Inversion Models and Laboratory Velocity

Measurements of Basement Rocks from the

LARSE I Transect

In Figure 5C-F, we compare laboratory measurements of velocities from selected rock samples collected along the LARSE I transect (McCaffree Pellerin and Christensen, 1998; Lutter et al., 1999) with velocity-depth curves from the final 2D and 3D models (Fig. 3B,C) at model coordinates $52.5,55,65$, and $75 \mathrm{~km}$.

South of the SAF (Fig. 5C-E), we compare our model curves with laboratory curves for gneiss and intrusive rocks of the San Gabriel Mountains, Pelona Schist, and Lowe Granodiorite. Model curves are generally higher than laboratory curves for all LARSE I rocks in the depth range $1-2 \mathrm{~km}$.

Between depths of 2 and $6 \mathrm{~km}$, model curves bracket laboratory curves for all LARSE I rock types at model distances of 52.5 and $55 \mathrm{~km}$, beneath outcrops of Pelona Schist (see Fig. 3). At model distance $65 \mathrm{~km}$, beneath outcrops of pre- $€$ ambrian gneiss and intrusive rocks and Mesozoic intrusive rocks, both model curves drop to relatively low velocities of $5.7-5.9 \mathrm{~km} / \mathrm{sec}$. Interestingly, these velocities only match those of the Pelona Schist as measured on the LARSE I transect.

North of the SAF (Fig. 5F), we compare our model curves with the Pelona Schist and gneiss and intrusive rocks of the Mojave Desert as measured on the LARSE I transect. Interestingly, both model curves are consistent with Pelona Schist at all depths $>1 \mathrm{~km}$, as measured on the LARSE I transect, but are not generally consistent with other rock types. We note in contrast that Fuis et al. (2001b) concluded from similar comparisons of lab and model curves on the LARSE I transect that Pelona Schist is not present in the Mojave Desert, although it underlies most of the central 
Transverse Ranges. Rock samples from the LARSE II transect must be collected and measured in the laboratory before any firmer interpretations of rock type are possible.

\section{Gravity Modeling along Line 2}

Gravity data along the LARSE II transect (Wooley and Langenheim, 2001) were reduced to Bouguer anomalies using a reduction density of $2670 \mathrm{~kg} / \mathrm{m}^{3}$. An additional isostatic correction was applied using a sea level crustal thickness of $25 \mathrm{~km}$, a crustal density of $2670 \mathrm{~kg} / \mathrm{m}^{3}$, and a mantlecrust density contrast of $400 \mathrm{~kg} / \mathrm{m}^{3}$. This correction removes long-wavelength gravitational effects of isostatic compensation of the crust due to topographic loading. The resulting gravity curve is termed the isostatic residual gravity anomaly and reflects, to first order, density variations within the middle and upper crust (Fig. 3A) (Simpson et al., 1986; Langenheim and Hauksson, 2001). Major features seen in both Bouguer and isostatic gravity fields are highs associated with the Santa Monica Mountains and the Transverse Ranges and lows coincident with the San Fernando, Santa Clarita, and Antelope Valleys.

We calculated the gravitational effect of the upper 10 $\mathrm{km}$ of the LARSE II 3D velocity model (Fig. 3C), assuming that density can be related to velocity in a straightforward way. For velocities $<5.5 \mathrm{~km} / \mathrm{sec}$, we used the densityvelocity relationship of Gardner et al. (1974) that was empirically derived from sedimentary rocks. The Gardner relationship is nearly identical to the density-velocity relationship obtained from a handful of wells in Los Angeles basin and San Fernando Valley (Langenheim et al., 2000). For velocities $>6 \mathrm{~km} / \mathrm{sec}$, the relationship of Christensen and Mooney (1995) developed for crystalline rocks at a depth of $10 \mathrm{~km}$ was utilized.

The effect of the Moho configuration beneath the profile, as yet unmodeled, most likely accounts for most or all of the long-wavelength disagreement between the complete Bouguer gravity (Wooley and Langenheim, 2001) and predicted values along the transect (Fig. 3A). The predicted gravity curve, especially that portion south of the Mojave Desert, fits better with the isostatic gravity data, as would be expected from the good agreement between isostatic gravity and a 3D velocity model of southern California (Langenheim and Hauksson, 2001). The predicted gravity curve approximately matches the locations of the observed gravity highs in the Santa Monica Mountains and central Transverse Ranges and of the gravity lows associated with the San Fernando and Santa Clarita Valleys. The observed gravity high in the Santa Monica Mountains is narrower and more pronounced than the predicted high, reflecting the loss of resolution below 2-km depth in the velocity model.

The match between the isostatic and predicted gravity values is poorer along the northern half of the transect (Fig. $3 \mathrm{~A})$. The velocity model predicts gravity values that are 20 $30 \mathrm{mGal}$ higher than the isostatic gravity values. Much of this mismatch may result from basement rocks that are characterized by lower densities than would be predicted from the high $(>6 \mathrm{~km} / \mathrm{sec})$ velocities seen in the Mojave Desert. A similar conclusion was reached based on modeling along the Mojave Desert section of the LARSE I transect (Godfrey et al., 2002). Densities measured on basement samples in the Mojave Desert average about $2670 \mathrm{~kg} / \mathrm{m}^{3}$ (Langenheim, 1999), whereas basement densities predicted from the LARSE II velocity model are $>2710 \mathrm{~kg} / \mathrm{m}^{3}$.

In the region of the Garlock Fault, the predicted gravity includes a local gravity low not seen in the observed isostatic and Bouguer gravity data (Fig. 3A). The mismatch is most likely the result of fracturing caused by the Garlock Fault. Fracturing has a more pronounced effect on reducing seismic velocity than density (Stierman and Kovach, 1979).

The interpretation discussed earlier does not fully explain the mismatch between the predicted and observed gravity lows over Antelope Valley. The amplitude of the observed gravity low over Antelope Valley $(30 \mathrm{mGal})$ is much greater than that predicted from the velocity model (10-15 mGal). The source of the disagreement in Antelope Valley may thus result from the choice of the densityvelocity relationship in the sedimentary sequence. In order to match the amplitude of the observed gravity low, lower densities are needed than are predicted from the velocity model using the relationship of Gardner et al. (1974). The Gardner relationship produces a model that fits the gravity anomalies well in the Los Angeles basin and San Fernando Valley. However, it is not surprising that it is not an appropriate density-velocity relationship for the Mojave Desert sedimentary basins, whose depositional history and setting are very different from those basins south of the SAF.

\section{Comparison of Our Inversion Models to Other Velocity Models}

We compare our DLS velocity model (Figs. 3B, 6A) with 2D slices from the recent Hauksson (2000) 3D tomographic velocity model for southern California (Fig. 6B) and the SCEC Community Velocity Model (CVM) (Fig. 6C) (Magistrale et al., 2000). The Hauksson (2000) model is parameterized at a $15-\mathrm{km}$ horizontal grid interval for the greater Los Angeles region. The SCEC CVM serves as a reference model for multidisciplinary research activities in the area. This latter model consists of detailed, rule-based representations of rocks filling the major southern California basins (Los Angeles basin, Ventura basin, San Gabriel Valley, San Fernando Valley, Chino basin, San Bernardino Valley) embedded in a 3D crust similar to that of Hauksson (2000).

As long as one keeps in mind the purposes and limitations of the three models we are comparing (Fig. 6A-C), velocities and velocity structure (contour shape) compare reasonably well among the three models. Our LARSE II study was designed chiefly to obtain details of sedimentary basins (rock velocity and basin shape) and also details of basement in the upper $5-10 \mathrm{~km}$ of the crust along a single profile. The finest grid spacing in our models was $0.5 \mathrm{~km}$. The study of Hauksson (2000) was designed chiefly to obtain gross ve- 

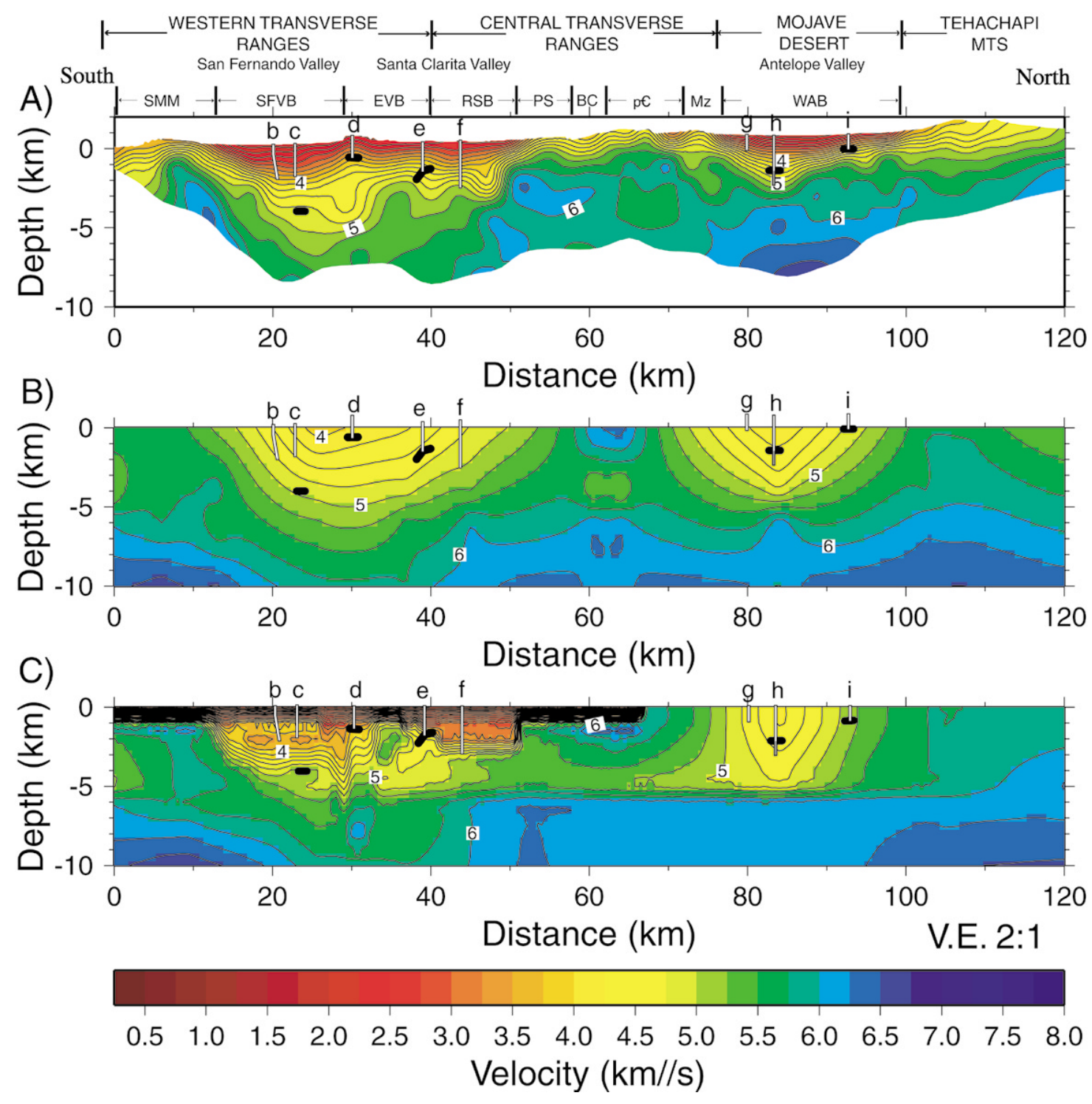

Figure 6. Velocity model comparison; isovelocity contour interval, $0.25 \mathrm{~km} / \mathrm{sec}$. (A) Final 2D DLS model (see Fig. 3B). (B) Velocity model from 3D southern California velocity model of Hauksson (2000). The end points of this 2D slice through Hauksson's model are shotpoint $8020\left(34.05^{\circ},-118.56^{\circ}\right)$ near the Pacific Coast and shotpoint 9360 $\left(35.26^{\circ},-118.41^{\circ}\right)$ in the southern Sierra Nevada. In the Hauksson (2000) parameterization, velocities are linearly interpolated between points with the depth grid points positioned at depths of $1,4,6,10,15,17$, and $22 \mathrm{~km}$. (C) SCEC CVM with same end points as in Figure 6B. Basement interfaces and oil-test well data from Figure 3 are superposed on all three models to permit detailed comparisons. In the model shown in panel (B), zero on the depth scale is sea level; in the model shown in panel (C), zero is an average elevation, which changes along line 2 .

locity structure of the crust of southern California to a depth of $25 \mathrm{~km}$, in order to better locate earthquakes. The finest horizontal grid spacing in his study was $15 \mathrm{~km}$. The model of Magistrale et al. (2000) was designed to include as much detail on sedimentary basin fill as is available from surface geology and oil-industry well data into the 3D model of Hauksson (2000). Consequently, the LARSE II model (Figs. $3 \mathrm{~B}, 6 \mathrm{~A})$ resolves greater detail on basin shape and sedimentary fill than the coarser-gridded Hauksson (2000) model
(Fig 6B) and is more comparable to the SCEC CVM of Magistrale et al. (2000) (Fig. 6C).

Sedimentary basin fill in the Antelope Valley in the model of Magistrale et al. (2000) and sedimentary basin fill in all valleys in the model of Hauksson (2000) have higher velocities at the surface and consequently greater depth extent than seen in our models of the LARSE II line. This feature is a consequence of the trade-off between velocity and fill thickness in basins in models derived from upcoming 
rays, from earthquake sources. The $6.0-\mathrm{km} / \mathrm{sec}$ contours (enclosing blue regions of Fig. 6) are also generally deeper in the Hauksson and Magistrale models than in the LARSE model, but all models show a deepening of this contour that is centered on the Santa Susana Mountains. Interestingly, all models also show a reversed velocity gradient in the upper crust of the central Transverse Ranges near the 60-km model coordinate.

Aftershocks of the San Fernando and Northridge Earthquakes

Aftershocks for the 1971 San Fernando and 1994 Northridge earthquakes are superimposed on our velocity model (Fig. 3C). These aftershocks were relocated using $V_{\mathrm{p}}$ and $V_{\mathrm{p}} / V_{\mathrm{s}}$ tomographic velocity models for southern California (Hauksson, 2000; Hauksson et al., 2002) that were improved using the LARSE II shots. A north-dipping low-velocity zone beneath the southern Santa Susana Mountains is centered on the aftershocks of the 1971 San Fernando earthquake and appears to lie above or north of the deep projection of the NHF (see Fig. 3C and Fuis et al., 2003a). Fuis et al. (2003a) interpreted the downward projection of the NHF to coincide with an upward projection of a deep reflective zone extending from the SAF to the hypocenter of the San Fernando earthquake. Fuis et al. (2003a) have shown abundant faulting in the hanging wall of this interpreted fault; such faulting may have produced the observed low-velocity zone.

\section{Seismic-Hazard Implications of Our Models}

Amplification of seismic waves occurs in sedimentary basin fill in several different ways, but the net effect seems to be that basins with deeper fill cause greater amplification (Field et al., 2000). This amplification can be comparable to and even greater than local site effects. For seismic hazard assessment, it is therefore important to know the depths and geometries of sedimentary basins in southern California. The LARSE II velocity models can now be used to improve the CVM of Magistrale et al. (2000), which is used to calculate seismic amplitudes for large scenario earthquakes. Our comparison in Figure 6 confirms that the CVM is approximately correct for maximum basin depth in the San Fernando Valley along the LARSE II corridor but can be significantly improved in the Antelope Valley.

\section{Conclusions}

We have used first-arrival travel times to construct tomographic $2 \mathrm{D}$ and $3 \mathrm{D}$ velocity models along the LARSE II transect. These models are similar to one another, indicating robustness in the modeling. However, the 3D model incorporates model smoothing that appears to smear model detail as evidenced by a lack of detail associated with surface faulting, including low-velocity zones and sharp velocity discontinuities. The geometry of basins and the velocities of rocks filling them are determined beneath the San Fernando, Santa Clarita, and Antelope Valleys. The sedimentary basin fill is characterized by relatively low velocities and high velocity gradients. The base of these regions of low velocities and steep velocity gradients corresponds approximately to velocity discontinuities modeled independently using LARSE II refraction data. These discontinuities are interpreted to correspond, in most cases, to the contact between Cenozoic sedimentary rocks and older basement rocks. Maximum basin depth along line 2 in the San Fernando Valley is $\sim 4.3$ $\mathrm{km}$, with the deepest point in the northern part of the valley. Maximum basin depth is $\sim 2.4 \mathrm{~km}$ in the Antelope Valley, and basement here includes both Mesozoic granitic rocks and lower Tertiary rocks.

Where the LARSE II transect crosses basement outcrop, the velocity (beneath the surficial layer of fractured, weathered rocks) is modeled as $5.75-6.0 \mathrm{~km} / \mathrm{sec}$ in the Santa Monica Mountains, $5.5-6.0 \mathrm{~km} / \mathrm{sec}$ in the central Transverse Ranges, and 5.25-6.25 km/sec in the southernmost Mojave Desert. The latter two regions are separated by a velocity contrast with differing velocity-depth profiles on either side of the SAF. Other fault zones whose surface expressions correlate with imaged detail in the LARSE II models include the SGF, Pelona Fault, and CF. Finally, a weak low-velocity zone beneath the Santa Susana Mountains is centered approximately on the north-dipping aftershock zone of the 1971 San Fernando earthquake and may represent fracturing in the hanging wall of the San Fernando Fault system.

Velocity-depth curves from laboratory measurements of rock samples along the LARSE I transect (McCaffree Pellerin and Christensen, 1998) can be tentatively used to interpret rocks along the LARSE II transect, although full interpretation awaits collection and lab measurements of rocks that actually crop out along the LARSE II transect.

Bouguer and isostatic gravity profiles compared to gravity values computed from our velocity model provide constraints on velocity-density assumptions for southern California terranes along the LARSE II transect. The gravity curve predicted from our model fits observed isostatic gravity data better south of the SAF than north, owing possibly to an improper velocity-density relationship for rocks and sediments of the Mojave Desert.

Taking into account the differing grid size (and resolution) and the differing data sources for our velocity model compared to velocity models of Hauksson (2000) and Magistrale et al. (2000), there is reasonable agreement among the models. The LARSE II model (Figs. 3B, 6A) resolves greater detail within the sedimentary basins than the coarsergridded Hauksson (2000) model and can be used to improve the model of Magistrale et al. (2000).

\section{Acknowledgments}

This research was supported by the U.S. Geological Survey, Department of the Interior (USGS Cooperative Agreement 00HQGR0053 and USGS internal funds), National Science Foundation (NSF Cooperative Agreement EAR-97-25413), Southern California Earthquake Center (SCEC, which is funded by NSF Cooperative Agreements EAR 8920136 and USGS Cooperative Agreements 14-08-0001-A0899 and 1434-HQ-97AG01718), 
Deutsche Forschungsgemeinschaft, and GeoForschungsZentrum Potsdam, Germany. The views and conclusions contained in this document are those of the authors and should not be interpreted as necessarily representing the official policies, either expressed or implied, of the U.S. government. Instruments were supplied by IRIS/PASSCAL, University of Texas El Paso, Geophysical Instrument Pool Potsdam, Canadian Geological Survey, University of Copenhagen, SCEC, and the USGS. The SCEC Contribution Number for this paper is 677 . The facilities of the IRIS Consortium are supported by the National Science Foundation under Cooperative Agreement EAR0004370. We are indebted to many government agencies, organizations, companies, and private individuals who granted permission and, in many cases, vital assistance to LARSE II (see table 3 in Fuis et al., 2001a). This manuscript benefited from reviews by Tom Brocher, Andy Michael, and Egill Hauksson.

\section{References}

Allen, C. R., G. R. Engen, T. C. Hanks, J. M. Nordquist, and W. R. Thatcher (1971). Main shock and larger aftershocks of the San Fernando earthquake, February 9 through March 1, 1971, in The San Fernando, California, Earthquake of February 9, 1971, U.S. Geol. Surv. Profess. Pap. 733, 17-20.

Allen, C. R., T. C. Hanks, and J. H. Whitcomb (1975). Seismological studies of the San Fernando earthquake and their tectonic implications, in San Fernando, California, Earthquake of 9 February 1971, G. B. Dakshott (Editor), California Division of Mines and Geology Bulletin 196, 257-262.

Brocher, T. M., A. L. Ruebel, T. L. Wright, and D. A. Okaya (1998). Compilation of 20 sonic and density logs from 12 oil test wells along LARSE Lines 1 and 2, Los Angeles region, California, U.S. Geol. Surv. Open-File Rept. 98-366, 53 pp.

Christensen, N. I., and W. D. Mooney (1995). Seismic velocity structure and composition of the continental crust: a global view, J. Geophys. Res. 100, 9761-9788.

Crouch, J. K., and J. Suppe (1993). Late Cenozoic evolution of the Los Angeles and inner California borderland: a model for core complexlike crustal extension, Geol. Soc. Am. Bull. 105, 1415-1434.

Crowell, J. C. (2003). Tectonics of Ridge Basin region, southern California, in Evolution of Ridge Basin, Southern California: An Interplay of Sedimentation and Tectonics, J. C. Crowell (Editor), Geol. Soc. Am. Special Paper 367, 157-203.

Dibblee, T. W., Jr. (1967). Areal geology of the western Mojave Desert, California, U.S. Geol. Surv. Profess. Pap. 522, 153 pp.

Dibblee, T. W., Jr. (1992). Geologic map of the Topanga and Canoga Park (south 1/2) quadrangles, Los Angeles County, California; Santa Barbara, California, Dibblee Geological Foundation, scale 1:24000.

Dibblee, T. W., Jr. (1996). Geologic map of the Newhall quadrangle, Los Angeles County, California; Santa Barbara, California, Dibblee Geological Foundation, scale 1:24000.

Field, E. H., and the SCEC Phase III Working Group (2000). Accounting for site effects in probabilistic seismic hazard analyses of southern California: overview of the SCEC Phase III Report, Bull. Seism. Soc. Am. 90, 6B, S1-S31.

Fuis, G. S., J. M. Murphy, D. A. Okaya, R. W. Clayton, P. M. Davis, K. Thygesen, S. A. Baher, T. Ryberg, M. L. Benthien, G. Simila, J. T. Perron, A. K. Yong, L. Reusser, G. Kaip, M. D. Fort, I. Asudeh, R. Sell, J. R. Vanschaack, E. E. Criley, R. Kaderabek, W. M. Kohler, and N. H. Magnuski (2001a). Report for borehole explosion data acquired in the 1999 Los Angeles Region Seismic Experiment (LARSE II), Southern California: Part I, Description of the survey, U.S. Geol. Surv. Open-File Rept. 01-408, 82 pp.

Fuis, G. S., T. Ryberg, N. J. Godfrey, D. A. Okaya, and J. M. Murphy (2001b). Crustal structure and tectonics from the Los Angeles basin to the Mojave Desert, southern California, Geology 29, 15-18.

Fuis, G. S., R. W. Clayton, P. M. Davis, T. Ryberg, W. J. Lutter, D. A. Okaya, E. Hauksson, C. Prodehl, J. M. Murphy, M. L. Benthien, S. A.
Baher, M. D. Kohler, K. Thygesen, G. Simila, and G. R. Keller (2003a). Fault systems of the 1971 San Fernando and 1994 Northridge earthquakes, southern California: relocated aftershocks and seismic images from LARSE II, Geology 31, 171-174.

Fuis, G. S., K. Thygesen, K. L. Lim, D. A. Okaya, S. Baher, G. Simila, J. M. Murphy, T. Ryberg, and V. E. Langenheim (2003b). Seismic structure of the San Fernando and Antelope Valleys, southern California: results from LARSE II refraction, industry reflection, and oiltest well data, EOS 84, no. 46, F1028.

Gardner, G. H., L. W. Gardner, and A. R. Gregory (1974). Formation velocity and density: the diagnostic basis for stratigraphic traps, Geophysics 39, 770-780.

Godfrey, N. J., G. S. Fuis, V. E. Langenheim, D. A. Okaya, and T. M. Brocher (2002). Lower crustal deformation beneath the central Transverse Ranges, southern California: results from the Los Angeles Region Seismic Experiment, J. Geophys. Res. 107, 10.1029/2002, ETG 8-1-ETG 8-19.

Hauksson, E. (2000). Crustal structure and seismicity distribution adjacent to the Pacific and North America plate boundary in southern California, J. Geophys. Res. 105, 13,875-13,903.

Hauksson, E., L. M. Jones, and K. Hutton (1995). The 1994 Northridge earthquake sequence in California: seismological and tectonic aspects, J. Geophys. Res. 100, 12,335-12,355.

Hauksson, E., G. Fuis, W. Lutter, and T. Ryberg (2002). A comparison of aftershock relocations and velocity models through the vicinities of the 1971 San Fernando and 1994 Northridge earthquakes: results from Combining LARSE and SCSN (CISN) data, EOS 83, no. 47, F1067.

Heaton, T. H. (1982). The 1971 San Fernando earthquake: a double event? Bull. Seism. Soc. Am. 72, 2037-2062.

Hendrix, E. D., and R. V. Ingersoll (1987). Tectonics and alluvial sedimentation of the upper Oligocene/lower Miocene Vasquez Formation, Soledad basin, southern California, Geol. Soc. Am. Bull. 98, 647-663.

Hole, J. (1992). Nonlinear high-resolution three-dimensional seismic travel time tomography, J. Geophys. Res. 97, 6553-6562.

Hornafius, J. S., B. P. Luyendyk, R. R. Terres, and M. J. Kamerling (1986). Timing and extent of Neogene tectonic rotation in the western Transverse Ranges, California, Geol. Soc. Am. Bull. 97, 1476-1487.

Jennings, C. W. (Compiler) (1977). Geologic map of California; Sacramento, California Division of Mines and Geology, Data Map 2, scale 1:750,000.

Langenheim, V. E. (1999). Gravity and aeromagnetic models along the Los Angeles region seismic experiment (LINE 1), California, U.S. Geol. Surv. Open-File Rept. 99-388.

Langenheim, V. E., and E. Hauksson (2001). Comparison between crustal density and velocity variations in southern California, Geophys. Res. Lett. 28, 3087-3090.

Langenheim, V. E., A. Griscom, R. C. Jachens, and T. G. Hildenbrand (2000). Preliminary potential-field constraints on the geometry of the San Fernando basin, southern California, U.S. Geol. Surv. Open-File Rept. 00-219.

Langenheim, V. E., T. G. Hildenbrand, R. C. Jachens, and A. Griscom (2001). Geophysical setting of the San Fernando Basin, southern California, in Geology and Tectonics of the San Fernando Valley and East Ventura Basin, T. L. Wright and R. S. Yeats (Editors), American Association of Petroleum Geologists, Pacific Section, GB77, 37-54.

Luetgert, J. H. (1992). MacRay: Interactive two-dimensional seismic raytracing for the Macintosh, U.S. Geol. Surv. Open-File Rept. 92-356, $43 \mathrm{pp}$.

Lutter, W. J., G. S. Fuis, C. H. Thurber, and J. R. Murphy (1999). Tomographic images of the upper crust from the Los Angeles Basin to the Mojave Desert, California: results from the Los Angeles Region Seismic Experiment, J. Geophys. Res. 104, 25,543-25,565.

Magistrale, H., S. Day, R. W. Clayton, and R. Graves (2000). The SCEC southern California reference three-dimensional seismic velocity model version 2, Bull. Seism. Soc. Am. 90, no. 6, S65-S76.

Matti, J. C., D. M. Morton, and B. F. Cox (1985). Distribution and geologic relations of fault systems in the vicinity of the central Transverse 
Ranges, southern California, U.S. Geol. Surv. Open-File Rept. 85365,27 pp., scale 1:250,000.

McCaffree Pellerin, C. L., and N. I. Christensen (1998). Interpretation of crustal seismic velocities in the San Gabriel-Mojave region, southern California, Tectonophysics 286, 253-271.

Meisling, K. E., and R. J. Weldon (1989). Late Cenozoic tectonics of the northwestern San Bernardino Mountains, southern California, Geol. Soc. Am. Bull. 101, 106-128.

Mooney, W. D., and S. Schapper (1995). Seismic refraction studies, in Major Results of Geophysical Investigations at Yucca Mountain and Vicinity, Southern Nevada, H. W. Oliver, D. A. Ponce, and W. C. Hunter (Editors), U.S. Geol. Surv. Open-File Rept. 95-74, 274 pp.

Mori, J., D. J. Wald, and R. L. Wesson (1995). Overlapping fault planes of the 1971 San Fernando and 1994 Northridge, California earthquakes, Geophys. Res. Lett. 22, 1033-1036.

Murphy, J. M., G. S. Fuis, D. A. Okaya, K. Thygesen, S. A. Baher, T. Ryberg, G. Kaip, M. D. Fort, I. Asudeh, and R. Sell (2002). Report for borehole explosion data acquired in the 1999 Los Angeles Region Seismic Experiment (LARSE II), southern California: Part II, Data tables and plots, U.S. Geol. Surv. Open-File Rept. 02-179, 252 pp.

Powell, R. E. (1993). Balanced palinspastic reconstruction of pre-Late Cenozoic paleogeology, southern California: geologic and kinematic constraints on evolution of the San Andreas fault system, in The San Andreas Fault System: Displacement, Palinspastic Reconstruction, and Geologic Evolution, R. Powell, R. Weldon, II, and J. Matti (Editors), Geol. Soc. Am. Memoir, Vol. 178, 1-106.

Ryberg, T., and G. S. Fuis (1998). The San Gabriel Mountains bright reflective zone: possible evidence of young mid-crustal thrust faulting in southern California, Tectonophysics 286, 31-46.

Shields, K. E. (1977). Structure of the northwestern margin of the San Fernando Valley, Los Angeles County, California, Master's Thesis, Ohio University, Athens.

Simpson, R. W., R. C. Jachens, R. J. Blakely, and R. W. Saltus (1986). A new isostatic residual gravity map of the conterminous United States with a discussion on the significance of isostatic residual anomalies, J. Geophys. Res. 91, 8348-8372.

Stierman, D. J., and R. L. Kovach (1979). An in situ velocity study: the Stone Canyon well, J. Geophys. Res. 84, 672-678.

Stitt, L. T. (1986). Structural history of the San Gabriel fault and other Neogene structures of the central Transverse Ranges, in Neotectonics and Faulting in Southern California, P. L. Ehlig (compiler), Geological Society of America, 82nd Annual Meeting of Cordilleran Section, March 25-28, 1986, Los Angeles, California, Guidebook and Volume for Field Trips 10, 12, 18, 43-102.

Thygesen, K. (2003). Seismic modeling and interpretations of the San Fernando Valley, southern California, Master's Thesis, Copenhagen University, $132 \mathrm{pp}$.

Tsutsumi, H., and R. S. Yeats (1999). Tectonic setting of the 1971 Sylmar and 1994 Northridge earthquakes in the San Fernando Valley, California, Bull. Seism. Soc. Am. 89, 1232-1249.

U.S. Geological Survey Staff (USGS Staff) (1971). Surface faulting, in The San Fernando, California, Earthquake of February 9, 1971, U.S. Geol. Surv. Profess. Pap. 733, 55-76.

Winterer, E. L., and D. L. Durham (1954). Geology of a part of the eastern Ventura basin, Los Angeles County, in Geology of Southern California, R. H. Jahns (Editor), California Division of Mines Bull. 170, Vol. 2, map sheet 5, scale 1:84,000.

Wooley, R. J., and V. E. Langenheim (2001). Gravity data along LARSE (Los Angeles Regional Seismic Experiment) Line 2, southern Cali- fornia, U.S. Geol. Surv. Open-File Rept. 01-375, http://wrgis.wr. usgs.gov/open-file/ of 01-375.

Wooley, R. J., V. E. Langenheim, and T. G. Hildenbrand (2001). Gravity and magnetic interpretations in the region of the LARSE II transect, southern California, EOS 82, no. 47, F806.

Yeats, R. F. (1987). Late Cenozoic structure of the Santa Susana fault zone, U.S. Geol. Surv. Profess. Pap. 1339, 137-160.

Yeats, R. S., G. J. Huftile, and L. T. Stitt (1994). Late Cenozoic tectonics of the east Ventura basin, Transverse Ranges, California, Am. Assoc. Petrol. Geol. Bull. 78, 1040-1074.

Zelt, C. A., and R. B. Smith (1992). Seismic traveltime inversion for 2-D crustal velocity structure, Geophys. J. Int. 108, 16-34.

University of Wisconsin

Madison, Wisconsin 53711

(W.J.L., N.I.C., C.H.T.)

U.S. Geological Survey

Menlo Park, California 94025

(G.S.F., J.M.M., V.E.L.)

GeoForschungsZentrum

Potsdam, 14473 Germany

(T.R.)

Southern California Earthquake Center (SCEC)

University of Southern California

Los Angeles, California 90089

(D.A.O., M.L.B., N.J.G.)

SCEC

California Institute of Technology

Pasadena, California 90025

(R.W.C.)

SCEC

University of California at Los Angeles

Los Angeles, California 90024

(P.M.D.)

Geophysikalisches Institut

Universitaet Karlsruhe

Karlsruhe D-76187, Germany

(C.P.)

University of Copenhagen

Denmark 1350

(K.T.)

California State University at Northridge

Northridge, California 91330

(G.S.)

Department of Geological Sciences

University of Texas at El Paso

El Paso, Texas 79968

(G.R.K.)

Manuscript received 24 March 2003. 